Bangladesh J. Bot. 43(2): 141-145, 2014 (September)

\title{
ROOT DISTRIBUTION OF ACACIA MANGIUM WILLD. AND MACARANGA TANARIUS L. OF RAINFOREST
}

\author{
NaZi Avani*, Habibah Lateh and Ghassem Habibi Bibalani ${ }^{1}$ \\ School of Distance Education, Universiti Sains Malaysia, P. Pinang
}

Key words: Root distribution, Fine roots, Acacia mangium, Macaranga tanarius, Rainforest

\begin{abstract}
The number of roots and root area ratio (RAR) decreased with depth in Acacia mangium and Macaranga tanarius and the maximum value of RAR and root number were observed in the first layer of soil. This process was regular in Acacia mangium Willd., but the RAR value showed great variability in Macaranga tanarius L. as the RAR decreased with depth until the second layer $(20 \mathrm{~cm})$ and increased again. About $35 \%$ of all roots in A. mangium, and about $50 \%$ of all roots in $M$. tanarius are located in the first layer. About $87 \%$ of all roots were in the fine root diameter class $(\mathrm{d}<2 \mathrm{~mm})$ in $M$. tanarius species. However $90 \%$ of all roots were in the fine root diameter class in A. magnium species. Fine roots contribution to soil reinforcement due to concentration on upper levels, prevent surface erosion and shallow landslide. These results will be useful for slope stability projects.
\end{abstract}

\section{Introduction}

Root area ratio (RAR) or index of root area is an amount of rotting mass in a soil. (Bischetti et al. 2005). Compared to tensile strength, the root area ratio was significantly more important in soil shear resistance. Docker and Hubble (2008) mentioned that there is a correlation between the amount of RAR and increased shear resistance. The root area index is defined by measuring the number of roots in different diameter classes in cross-sectional area of soil exposed on a vertical face of soil (De Baets et al. 2008).

Root distribution of three hardwood species in northern of Iran was compared by Abdi et al. (2010a). The number of roots and root area ratio (RAR) decreased with depth, but the number of roots showed the regular pattern of decrease with depth compared to RAR. This is because of the presence of large roots, that RAR values are very sensitive to this factor. Also, the results showed that in larger trees, anchorage occur by increasing in the growth of root diameters but not by increasing in the number of roots. Also in other research, the effect of two species on slope stability was investigated by Ji et al. (2012). There was a significant difference in mean RAR between the two species and the amount of RAR is higher in Robinia pseudoacacia, which were much bigger than Platycladus orientalis. For both the species maximum RAR values were located in the first $30 \mathrm{~cm}$ layer, and showed a decrease in the RAR values with depth.

The aim of this study is to compare the characteristic of the root system or root distribution in two species of tropical forests which is important for selecting species for erosion control and slope stability.

\section{Material and Methods}

The study area is located along east-west highway in Malaysia, which is one of the major roads in the northern part of Malaysia between $\mathrm{N} 05^{\circ} 27^{\prime} 32.0^{\prime \prime} \mathrm{E} 101^{\circ} 07^{\prime} 42.3^{\prime \prime}$ and $\mathrm{N} 5^{\circ} 42^{\prime}$ 11.15" E $101^{\circ} 49^{\prime}$ 54.74". This highway links Gerik in Perak and Jeli in Kelantan with the length

*Author for correspondence: <avani.nazi@yahoo.com>. ${ }^{1}$ Department of Forestry, Shabestar Branch, Islamic Azad University, Shabestar City, East Azerbaijan, Iran. 
of $119 \mathrm{~km}$. The climate is humid and an annual mean precipitation is about $1957.5 \mathrm{~mm}$. The altitude is 283 meters above the sea. The type of soil is sandy, clay and loam and the lithology consist of Schist, phyllite, slate and limestone.

Macaranga tanarius L. is one of the species of Euphorbiaceae which occurs in disturbed rainforest areas. This pioneer species can tolerate in a wide range of soil type including clay, loam and sand. Macaranga tanarius is cultivated for ornament and reforestation projects in the tropical regions around the world. It is native to Malaysia and the average annual rainfall between 100 and $200 \mathrm{~cm}$, and the average temperature between 10 and 20 degrees in January to over 20 degrees in July is suitable for its growing.

Acacia mangium Willd. fix nitrogen in the soil, which is useful for other plants, therefore cultivated in mixed cultures and for agroforestry projects (Jeyanny et al. 2011). Due to intensive rooting system of A. mangium, especially in poor soils (Kadir et al. 1998) this species cultivated in disturbed tropical regions.

The root distribution in the soil was analyzed by counting roots directly using a profile trench (Preti and Giadrossich 2009). At first, four trees of each species were selected. Then, under each species sample, one trench with $50 \mathrm{~cm}$ of length and depth with a distance about $25 \mathrm{~cm}$ from the stem was dug. In consequence, roots were counted in the separate $10 \mathrm{~cm}$ of soil layers. The average diameter (breast height) in Macaranga species was about $13 \mathrm{~cm}$ and that in Acacia species was $27 \mathrm{~cm}$. The soil conditions were the same under the samples, but there was shallow bedrock under Acacia trees.

After that, a profile wall of trenches which close to tree stem were marked in every $10 \mathrm{~cm}$ thickness, then the number of roots was counted and divided in different root diameter classes i.e., $0-1,1-2,2-5,5-10$ and $>10 \mathrm{~mm}$ (as the average root diameter in the root length). According to Ji et al. (2012) and Genet et al. (2008) roots belong in the first two ranges will classify as fine roots and the other second root diameter ranges consider as thin roots. Then the RAR percentage was calculated in each depth. The occupied area of roots in each layer was calculated by the following equation:

$$
\text { Root area }=\sum_{i=1}^{n} \frac{\pi}{4} d i^{2}
$$

$\mathrm{D}_{\mathrm{i}}$, is the diameter of roots in each layer and root area is the area that occupied by roots in soil. Then the root area ratio (RAR) was calculated by the following equation:

$$
\mathrm{RAR}=\sum_{i=1}^{n} \frac{A r i}{A}
$$

In this equation $\mathrm{A}_{\mathrm{ri}}$ is the area that occupied by roots in each layer and $\mathrm{A}$ is the area of soil in each layer (Comino and Marengo 2010).

Statistical software of SPSS 20 was used to analyze data. RAR values from the two species were compared using paired-samples $\mathrm{T}$ tests. For assessing the best model between RAR and soil depth, various functions were tested, and the function that show not only the highest $\mathrm{R}^{2}$ but also the lowest standard error was chosen as the best model. Spearman correlation was used to correlate the relation between RAR and soil depth.

\section{Results and Discussion}

The number of roots at each depth class showed a more systemic trend when compared with RAR values (Tables 1-4). The function between the number of roots and depth showed that 
number of roots decreased with depth following a power law for $M$. tanarius $\left(\mathrm{R}^{2}=0.818\right.$, SE of estimate $=0.361)$, and following exponential for A. mangium $\left(R^{2}=0.378\right.$, SE of estimate $\left.=0.592\right)$. The amount of RAR values declined with depth following exponential for A. mangium $\left(\mathrm{R}^{2}=\right.$ 0.536 , $\mathrm{SE}$ of estimate $=0.975)$, and for $M$. tanarius following by $\mathrm{S}\left(\mathrm{R}^{2}=0.138\right.$, SE of estimate $=$ $1.141)$.

$\mathrm{T}$ tests result showed that there is not a significant difference in the percentage of RAR $(\mathrm{F}=0.283, \mathrm{p}>0.05)$ and root numbers $(\mathrm{F}=0.040, \mathrm{p}>0.05)$ between two species.

Table 1. Distribution of number of roots at different soil depth in Macaranga tanarius.

\begin{tabular}{lccccc}
\hline \multirow{2}{*}{$\begin{array}{l}\text { Soil depth } \\
(\mathrm{cm})\end{array}$} & \multicolumn{5}{c}{ Number of roots at different root diameter classes } \\
\cline { 2 - 6 } & $0-1(\mathrm{~mm})$ & $1-2(\mathrm{~mm})$ & $2-5(\mathrm{~mm})$ & $5-10(\mathrm{~mm})$ & $>10(\mathrm{~mm})$ \\
\hline 10 & 185 & 64 & 10 & 6 & 3 \\
20 & 81 & 24 & 4 & 1 & 0 \\
30 & 39 & 19 & 15 & 0 & 0 \\
40 & 26 & 9 & 11 & 1 & 0 \\
50 & 14 & 9 & 6 & 7 & 0 \\
\hline
\end{tabular}

Table 2. Distribution number of roots in soil depth in Acacia mangium.

\begin{tabular}{lccccc}
\hline \multirow{2}{*}{$\begin{array}{l}\text { Soil depth } \\
(\mathrm{cm})\end{array}$} & \multicolumn{5}{c}{ Number of roots at different root diameter classes } \\
\cline { 2 - 6 } & $0-1(\mathrm{~mm})$ & $1-2(\mathrm{~mm})$ & $2-5(\mathrm{~mm})$ & $5-10(\mathrm{~mm})$ & $>10(\mathrm{~mm})$ \\
\hline 10 & 145 & 57 & 29 & 3 & 3 \\
20 & 95 & 44 & 9 & 1 & 1 \\
30 & 85 & 25 & 7 & 0 & 0 \\
40 & 71 & 17 & 1 & 0 & 0 \\
50 & 57 & 11 & 5 & 0 & 0 \\
\hline
\end{tabular}

Table 3 shows the percentage of RAR in each diameter class in two species. As recognized with the table about $72 \%$ of all roots in A. mangium are located in the diameter root classes with less than $10 \mathrm{~mm}$ and this amount is about $85 \%$ for M. tanarius.

Table 3. Percentage of different root classes to RAR values.

\begin{tabular}{llllll}
\hline Species & \multicolumn{5}{c}{ \% of RAR at different root diameter } \\
\cline { 2 - 6 } & $0-1 \mathrm{~mm}$ & $1-2 \mathrm{~mm}$ & $2-5 \mathrm{~mm}$ & $5-10 \mathrm{~mm}$ & $>10 \mathrm{~mm}$ \\
\hline A. mangium & 6.32 & 18.24 & 34.91 & 12.57 & 27.94 \\
M. tanarius & 4.05 & 13.19 & 26.44 & 42.23 & 14.08 \\
\hline
\end{tabular}

By comparing RAR values in fine roots $(\mathrm{d}<2 \mathrm{~mm})$ and thin roots $(2<\mathrm{d}<10 \mathrm{~mm})$, in $A$. mangium, fine roots and thin roots decline with depth regularly, but there is an exception in the root diameter classes of $2-5 \mathrm{~mm}$ in the $50 \mathrm{~cm}$ soil depth (Table 4).

The highest RAR value was in the $2-5 \mathrm{~mm}$ root diameter class and the lowest RAR value were in the first layer in A. mangium (34.91, 6.32\%, respectively) (Table 3).

There was a wide variety in the RAR distribution in the root diameter classes of 2 - 5 and 5 $10 \mathrm{~mm}$ in M. tanarius. As in the diameter class of $2-5 \mathrm{~mm}$, the amount of RAR decreased until 
the second layer, then increased again until the last layer. This process repeated in the root diameter classes of $5-10 \mathrm{~mm}$, at the first the amount of RAR decreased until $30 \mathrm{~cm}$ soil depth and then again increased. The largest value of RAR was in the $5-10 \mathrm{~mm}$ root diameter classes and the lowest was in the first layer (42.23, 4.05 respectively) (Tables 5 and 3).

Table 4. Contribution RAR values in per cent in different size classes at each depth $(n=4$ replications) in A. mangium.

\begin{tabular}{llllll}
\hline \multirow{2}{*}{$\begin{array}{l}\text { Soil depth } \\
(\mathrm{cm})\end{array}$} & \multicolumn{5}{c}{ Root diameter $(\mathrm{mm})$} \\
\cline { 2 - 6 } & $0-1(\mathrm{~mm})$ & $1-2(\mathrm{~mm})$ & $2-5(\mathrm{~mm})$ & $5-10(\mathrm{~mm})$ & $>10(\mathrm{~mm})$ \\
\cline { 2 - 5 } & 2.02 & 7.16 & \% RAR values & \\
\hline 10 & 1.32 & 5.53 & 6.16 & 9.43 & 16.76 \\
20 & 1.18 & 3.14 & 4.79 & 0 & 0 \\
30 & 0.99 & 1.57 & 0.68 & 0 & 0 \\
40 & 0.79 & 0.82 & 3.42 & 0 & 0 \\
50 & & & & \\
\hline
\end{tabular}

Table 5. Contribution RAR values in per cent in different size classes at each depth ( $\mathrm{n}=4$ replications) in M. tanneries,

\begin{tabular}{llllll}
\hline \multirow{2}{*}{$\begin{array}{l}\text { Soil depth } \\
(\mathrm{cm})\end{array}$} & \multicolumn{5}{c}{ Root diameter } \\
\cline { 2 - 6 } & $0-1(\mathrm{~mm})$ & $1-2(\mathrm{~mm})$ & $2-5(\mathrm{~mm})$ & $5-10(\mathrm{~mm})$ & $>10(\mathrm{~mm})$ \\
\cline { 2 - 6 } & 2.17 & 6.75 & 5.75 & 15.84 & 14.08 \\
10 & 0.95 & 2.53 & 2.30 & 2.64 & 0 \\
20 & 0.45 & 2.01 & 8.62 & 0 & 0 \\
30 & 0.31 & 0.95 & 6.32 & 5.28 & 0 \\
40 & 0.16 & 0.95 & 3.45 & 18.48 & 0 \\
50 & &
\end{tabular}

The results indicated that more than $75 \%$ of all roots are smaller than $10 \mathrm{~mm}$ in diameter. Also Abdi et al. (2010b) mentioned that about $60 \%$ of the roots are smaller than $10 \mathrm{~mm}$ of root diameter. Some authors (De Baets et al. 2008, Abdi et al. 2010a, Chiaradia et al. 2012) considered these roots in soil reinforcement, but the other authors such as Styczen and Morgan (1995) indicated that roots $1-20 \mathrm{~mm}$ in diameter have the most important role in soil reinforcement.

The root area ratio is an important key for understanding about soil reinforcement by roots as an important factor in soil bioengineering. Therefore, for upgrading the knowledge about the effect of vegetation on slope stability, root area ratio data are useful for this kind of studies.

\section{Acknowledgement}

The authors thank Universiti Sains, Malaysia for the financial support through PRGS research grant 1001/PJJAUH/846090 and MOHE grant 203/PJJAUH/6711279.

\section{References}

Abdi E, Majnounian B, Genet M and Rahimi H 2010a. Quantifying the effects of root reinforcement of Persian Ironwood (Parrotia persica) on slope stability; a case study: Hillslope of Hyrcanian forests, northern Iran. Ecol. Enginee. 36: 1409-1416.

Abdi E, Majnonian B, Rahimi H, Zobeiri M, Mashayekhi Z and Yousefzadeh H 2010b. A comparison of root distribution of three hardwood species grown on a hillside in the Caspian forest, Iran. J. For. Res. 15: 99-107. 
Bischettti GB, Chiaradia EA, Simonato T, Speziali B, Vitali B, Vullo P and Zocco A 2005. Root strength and root area ratio of forest species in Lombardy (Northern Italy). Plant and Soil 278: 11-22.

Chiaradia E, Bischetti GB and Vergani C 2012. Incorporating the effect of root systems of forest species into spatially distributed models of shallow landslides. Inter. J. F. Soil and Erosion (IJFSE), 2: 107-118.

Comino E and Marengo P 2010. Root tensile strength of three shrub species: Rosa canina, Cotoneaster dammeri and Juniperus horizontalis. Soil reinforcement estimation by laboratory tests. Catena 82: 227235.

De Baets S, Poesen J, Reubens B, Wemans K, Beardemaeker JD and Muys B 2008. Root tensile strength and root distribution of typical Mediterranean plant species and their contribution to soil shear strength. Plant and Soil 305: 207-226.

Docker BB and Hubbel TCT 2008. Quantifying root-reinforcement of river bank soils by four Australian tree species. Geomorphology 100: 401-418.

Genet M, Kokotse N, Stokes A, Fourcaud T, Cai X, Ji J and Mickovski S 2008. Root reinforcement in plantations of Cryptomeria Japanica D. Don: effect of tree age and stand structure on slope stability. For. Ecol. Manag. 250: 1517-1526.

Jeyanny V, Lee SS and Wan Rasidah K 2011. Effect of arbuscular mycorrhizal and fertilization on the growth of Acacia mangium seedlings. J. Trop. For. Sci. 23(4): 404-409.

Ji J, Kokutse N, Genet M, Fourcaud T and Zhang Z 2012. Effect of spatial variation of tree root characteristics on slope stability. A case study on Black Locust (Robinia pseudoacacia) and Arbovitae (Platycladus orientalis) stands on the Loess Plateas, China. Catena 92: 139-154.

Kadir WR, Kadir AA, Van Cleemput O and Rahman ZA. 1998. Field grown Acacia mangium: How intensive is root growth? J. Trop. For. Sci. 10(3): 283-29.

Preti F and Giadrossich F 2009. Root reinforcement and slope Bioengineering stabilization by Spanish Broom (Spartium junceum L.). Hydrol. Earth Syst. Sci. 13: 1713-1726.

Styczen ME and Morgan RPC 1995. Engineering properties of vegetation. In: Slope stabilization and erosion control: a bioengineering approach. Morgan RPC, Rickson RJ (eds) E\&FN Spon, London.

(Manuscript received on 18 June, 2013; revised on 27 February, 2014) 